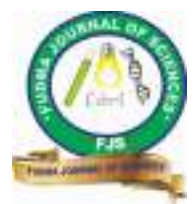

FUDMA Journal of Sciences (FJS)

ISSN online: $2616-1370$

ISSN print: 2645 - 2944

Vol. 4 No. 3, September, 2020, pp $267-274$

DOI: https://doi.org/10.33003/fjs-2020-0403-391

\title{
ANTI-TERMITE EFFECT OF ANADELPHIA AFZELIANA (RENDLE) STAPF EXTRACTS ON SELECTED WOOD SPECIES IN MAKURDI, BENUE STATE, NIGERIA
}

\author{
Okechukwu G. C., Agbidye, F. S., Tembe E. T. and *Ekhuemelo, D. O. \\ Department of Forest Production and Products, Federal University of Agriculture, Makurdi, Benue State, Nigeria \\ *Corresponding Author's email: davidekhuemelo@gmail.com ; +234(0)703-133-2803
}

\begin{abstract}
This study examined anti-termite effect of Anadelphia afzeliana extracts on Daniellia oliveri, Gmelina arborea and Terminalia ivorensis wood species in Makurdi, Nigeria. A. afzeliana was collected, dried under shade, pulverized and the phytochemical constituents of screened. Weight of $100 \mathrm{~g}$ was respectively dissolved in $200 \mathrm{~mL}$ of methanol and hot water and mixtures left to macerate within 24 hours and thereafter filtered to obtain extracts. Concentrations of $20 \%, 30 \%$ and $50 \%$ were constituted from methanol and aqueous extracts.Test woods were weighed and impregnated in treatments for 72 hours, after which absorption and retention were calculated. Treated woods were laid out in a timber grave yard in a Completely Randomized Design with seven treatments and solignum as control. Grand total of 360 test wood were used. Percentage weight loss was calculated on test wood. Anthraquinones, balsams, flavonoids, phlobatannins, tannins, terpens, resins, phenols and saponins phytochemicals were present in A. afzeliana. Mean absorption of $G$. arborea, T. ivorensis and D. oliveri test wood were $93.04-130.55 \mathrm{~kg} / \mathrm{m}^{3}, 100.54-142.04 \mathrm{~kg} / \mathrm{m}^{3}$ and 96.94 $175.01 \mathrm{~kg} / \mathrm{m}^{3}$, respectively. The values were lowest in solignum and highest in $20 \%$ A. afzeliana aqueous extract. Mean retention in G. arborea, T. ivorensis and D. oliveri were $9.29-62.51 \mathrm{~kg} / \mathrm{m}^{3}, 11.29-90.78$ $\mathrm{kg} / \mathrm{m}^{3}$ and $10.79-55.69 \mathrm{~kg} / \mathrm{m}^{3}$; lowest in solignum and highest in $50 \%$ A. afzeliana aqueous extract. Mean percentage weight loss was $13.81-30.65 \%$ (G. arborea), $13.37-23.31 \%$ (D. oliveri) and $36.07-86.11 \%$ (T. ivorensis) with solignum the most effective treatment followed by $20 \% \mathrm{~A}$. afzeliana methanol extract. It was there concluded that outside solignum, $20 \% \mathrm{~A}$. afzelia methanol extract was the most efficient while $T$. ivorensis wood was the most resistant to termite attack.
\end{abstract}

Keywords: Absorption, A. afzeliana, extract, retention, termites, weight loss.

\section{INTRODUCTION}

Anadelphia afzeliana (Rendle) Stapf commonly called Thatch grass (English) and occurs from Senegal eastward, southward to western region of Africa in Nigeria. It is an annual grass with height ranging from $30-60 \mathrm{~cm}$ in stems which is used for thatching and foraging (Bagué, 2011). Young growth is grazed and fully grown are mainly used locally for building thatch houses. Thatching material from A. afzeliana is of high quality because it has been observed that they not attacked by termites when in service. In Nigeria, it has even been described as the best thatching material available and are mostly found in the northern and eastern region of Nigeria, precisely Benue and Enugu States. The Tiv people of Benue State call it "Acho" while the local people of Enugu State refer to it as "Iruruwe". There are no accessions of $A$, afzeliana in gene banks (Brink and Achigan-Dako, 2012).

Wood is one of the most important renewable bio-resources used by mankind since prehistoric days (Falemara et al., 2012). It contains some major compounds such as cellulose, hemicelluloses and lignin (Unger et al., 2001).The amount of these compounds varies from species to species. Wood is an exceptionally resourceful material with an extensive range of physical and mechanical properties (Jerrold, 2005). Wood is being used for making weapons, farm implements, constructing shelters, furniture, cooking utensils, internal and external decorations, fuel and industrial purpose among others. As the world population increases, the demand for wood to meet the ever increasing human needs is also increasing, which is why the planting of trees should also increase and preservation of wood in service enhanced.

Like other lignocellulosic materials, wood is prone to degradation and dimensional variation on exposure to moisture, heat and biological agents like fungi, termites and wood boring insects which makes it unfit for further use (Sonowal and Gogoi, 2010). Wood preservation is a process of reducing and/or preventing attack by wood deteriorating agents thereby increasing the service life of wood (Barnes, 1992). Wood is exposed to numerous biological degradations in different environments and biological degradations occur when a $\log$, sawn product, or final product is not stored, handled, or designed properly (Owoyemi and Olaniran 2014). When wood is used as a construction material, it is generally treated with a chemical preservative to prevent damage by bio-deteriorating agents (Goktas et al., 2007).

Bio-deterioration has been one of the major problems of wood in service which has been addressed by impregnation and other methods with appropriate chemical preservatives depending on the area of use. In other to protect wood from degradation and enhance its service life, various methods have been employed which include: treating with mineral oil, coal tar, heating in hydrocarbon oil and treatment with Copper-chrome-arsenic 
(CCA). These synthetic chemicals are very expensive and often harmful to the workers and the environment (Connell, 1991).

Kartal et al. (2004) reported that, great interest has been focused on some wood preservatives that are cheap, effective and have minimal toxicity to mammals and the environment. Ability of wood and natural plant extractives to protect wood against wood degrading fungi and insects has been one possible approach for developing new wood preservatives. The use of traditional plant materials in the management of insect pests such as termite control which is cheap, easily reached and assembled in the developing countries had been reported by Owusu (2000). Though most of these traditional methods are of little use in the developed countries, they still play a significant role in pest control programs in the developing countries (Sotannde et al., 2011).

Termites are insect pests that are characterized by being social because of their ability to stay in a group; they feed on dead plant material mostly, and wood leaf litter and cowdung (Ezeji, 1984). Termites live in communities and feed on wood substance called cellulose. Termites are very destructive to wood material as they feed on its cellulose component which in turn reduces the structural capability and the aesthetic appeal. Wood and wood products like paper, fabrics and wood structures are avidly consumed by termites because they compose of cellulose which is the major food of termites which is why continual efforts are directed on their control (Peralta $e t$ al., 2004). Deterioration of wood materials by termites has become a persistent challenge in Nigeria; causing upsurge in monetary and material wastes which is one of the reasons responsible for increasing demand for timber (Obi et al., 2008). There are several efforts and approaches on termite control which have majorly being synthetic chemicals with their human and environmental problems.

The objective of this study therefore was to investigate the antitermite activities of $A$. afzeliana extracts on $G$. arborea, $T$. ivorensis, $D$. oliveri wood species with the view of exploring its potentials for wood preservation.

\section{MATERIALS AND METHODS}

\section{Collection of and preparation of materials}

Defect free sawn wood of D. oliveri, G. arborea and $T$. ivorensis were purchased from Timber Shed, Makurdi and processed into $2 \times 2 \times 4 \mathrm{~cm}$ (width $\times$ breath $\times$ length) dimensions. Methanol used for extraction and solignum solvent used as controls were also procured from chemical shop in Makurdi. Processed sawn wood test samples were air-dried for 30 days according to Ekhuemelo et al. (2017). Anadelphia afzeliana was collected from Vandeikya Local Government Area of Benue State during the raining season and dried under shade for some days and pulverized. The pulverized sample was sieved with $2 \mathrm{~mm}$ sieve.

\section{Preliminary Phytochemical screening of $A$. afzeliana} Methods of Mbahi et al. (2018); AOAC (2010) were adopted for the phytochemical screening tests for the presence of Anthraquinones, balsams, flavonoids, glycosides, phenols, phlobatannins, resins, saponins, sterols, tannins and terpens in A. afzeliana.

\section{Crude extraction of Anadelphia afzeliana}

Pulverized sample of $100 \mathrm{~g}$ was dissolved in $200 \mathrm{~mL}$ of methanol and hot water at $100{ }^{\circ} \mathrm{C}$ and the mixtures left to macerate for 24 hours and thereafter filtered to obtain $A$. afzeliana extracts which were fanned to dry. Concentrations of $20 \%, 30 \%$ and $50 \%$ of methanol and aqueous extracts were constituted by two-fold serial dilution. These concentrations of extracts (treatments) were used as treatments to impregnate the test wood samples.

Preparation and impregnation of wood sample test blocks Processed woods were dried and weighed $\left(\mathrm{W}_{1}\right)$ before impregnation into the experimental treatments. After 72 hours, the wood samples were removed from the treatments (extracts and solignum) and reweighed as $\mathrm{W}_{2}$. Test wooden blocks from each wood species were well labeled for easy identification and were then completely immersed into the different treatments for 72 hours, removed and air-dried for another 6 hours before burial. At the end of the experiment samples were reweigh $\left(\mathrm{W}_{3}\right)$ to calculate percentage weight loss of treated wood samples.

\section{Experimental design}

The treated wood samples were laid down in a Completely Randomized Design (CRD) in seven treatments (3 aqueous extracts, 3 methanol extracts, a +ve control (solignum) and -ve control (untreated woods). For each Treatment, test woods were replicated three times. Five wood samples were laid for each treatment, given a total of forty (40) test samples for each wood species in each replicate. A total of 120 wood samples were for each species; given a grand total of three hundred and sixty (360) wood samples for the three species. The treatments and control were:

1. $20 \%$ A. afzeliana Aqueous Extract (20\% AAE)

2. $30 \%$ A. afzeliana Aqueous Extract (30\% AAE)

3. $50 \%$ A. afzeliana Aqueous Extract (50\% AAE)

4. $20 \%$ A. afzeliana Methanol Extract (20\% AME)

5. $30 \%$ A. afzeliana Methanol Extract (30\% AME)

6. $50 \%$ A. afzeliana Methanol Extract (50\% AME)

7. Solignum solvent (+control)

8. Untreated wood (-control)

The treated wood samples were buried at the timber grave yard located at North-core, University of Agriculture, Makurdi for a period of 14 weeks. At each position of the test block, soil was excavated to a depth of $10 \mathrm{~cm}$ to ensure test block were completely buried. The spacing was 1 meter between holes and 3 meters between replicates.

\section{Experimental Layout and data collection}

A plot of 16 by 12 meters was mapped out in termites infested area. Eight holes of $10 \mathrm{~cm}$ depth were dug along the length of the mapped out area at every $1 \mathrm{~m}$ and it was replicated three times.

Inspection and evaluation of the wood samples were made on an interval of two weeks for the period of 14 weeks. On each visit, wood samples were removed from the ground and cleaned; attack on each of the wood sample was assessed in two ways

i. Incidence of attacked was recorded using: 
- Not attacked

+ Attacked

Severity of damaged was recorded by weighing the wood samples to calculate percentage weight loss.

Determination of absorption, retention of treatments and percent weight loss of wood samples: The absorption and retention of the extracts in wood and percent weight loss of treated wood samples were calculated according standard methods reported by Tascioglu et al. (2013); Adedutan (2015); Ekhuemelo et al.(2018a); Emerhi et al. (2015); Adedeji et al. (2013) using the following equations:

Absorption $\left(\mathrm{kgm}^{-3}\right)=\frac{1000(G)}{V} \quad \ldots \ldots \ldots \ldots \ldots[1]$
Retention $\left(\mathrm{kgm}^{-3}\right)=\left[\frac{(G \times C)}{V}\right] \times 10 \quad \ldots \ldots \ldots .[2]$

$\% W L=[(W 3-W 2) / W 2] \times 100$

Where:

$\mathrm{G}=\left(\mathrm{w}_{2}-\mathrm{w}_{1}\right)=$ amount of the treating solution absorbed by the test wood blocks $(\mathrm{g})$,

$\mathrm{W}_{1}=$ the oven dried weight of the conditioned wood blocks before treatment $(\mathrm{g})$,

$\mathrm{W}_{2}=$ the weight of the treatment,

$\mathrm{WL}=$ weight loss

$\mathrm{V}=$ volume of wood test block $\left(\mathrm{m}^{3}\right)$ and

$\mathrm{C}=$ is the concentration level of the solution or extracts $(20 \%$, $30 \%$ and $50 \%$ ).
Visual Rating of Treated woods Sample after Preservative Treatments

Percentage weight loss resulting from attack by termites was rated $0-6$ as: $0 \%$ no attack; 1 to $20 \%$ (slightly attacked); $21-$ $40 \%$ (moderately attacked); $41-60 \%$ (moderate/severe attacked); $61-80 \%$ (severely attacked); $81-99 \%$ (very severely attacked) and $100 \%$ (complete destruction).

\section{Data Analysis}

The data collected from the experiment were analyzed using descriptive statistic. Analysis of Variance was used to determine significant effects of treatment on wood samples while, a follow up test was carried out using Duncan Multiple Range Test where significant differences existed.

\section{RESULTS}

Phytochemical contents of $A$. afzelia extract

Anthraquinones, balsams, flavonoids, phlobatannins, tannins and terpens were moderately present $(++)$ in methanol extract, while, resins, phenols and saponins were fairly present $(+)$ in aqueous extract. Phlobatannins, saponins and resins were moderately present $(++)$ in aqueous extract; while, flavonoids was fairly present $(+)$ in aqueous extract. Glycosides and sterols were completely absent (-) in both methanol and aqueous $A$. afzelia extracts, while, anthraquinones, balsams, phenols, tannins and terpens were completely absent (-) in aqueous extract (Table 1).

Table 1: Phytochemical contents of $A$. afzelia extracts

\begin{tabular}{lcc}
\hline Phytochemical & Methanol extract & Aqueous extract \\
\hline Anthraquinones & ++ & - \\
Balsams & ++ & - \\
Flavonoids & ++ & + \\
Glycosides & - & - \\
Phenols & + & - \\
Phlobatannins & ++ & ++ \\
Resins & + & ++ \\
Saponins & + & ++ \\
Sterols & - & - \\
Tannins & ++ & - \\
Terpens & ++ & - \\
\hline Key: ++ Moderately present $;$ - Fairly present; - Absent &
\end{tabular}

\section{Absorption of extracts by treated wood species}

Gmelina arborea wood samples recorded mean absorption between 93.04 and $130.55 \mathrm{~kg} / \mathrm{m}^{3}$, lowest in solignum and highest in $20 \%$ A. afzeliana aqueous extract; while, in T. ivorensis wood, the mean value ranged from $100.54-142.04 \mathrm{~kg} / \mathrm{m}^{3} ; \mathrm{least}$ in solignum and maximum in $50 \%$ A. afzeliana aqueous extract. Mean absorption of $96.94-175.01 \mathrm{~kg} / \mathrm{m}^{3}$ was recorded for $D$. oliveri test samples. There were no significant differences $(\mathrm{p}>0.05)$ among treatments in G.arborea species while significant differences existed in D. oliveria and T. ivorensis wood species (Table 2). 
Table 2: Absorption of Extracts by Three Selected Treated Wood Species

\begin{tabular}{|c|c|c|c|}
\hline \multirow[t]{2}{*}{ Treatments } & \multicolumn{3}{|c|}{ Wood species } \\
\hline & $\begin{array}{l}\text { G. arborea } \\
\text { Mean }\left(\mathrm{Kg} / \mathbf{m}^{3}\right)\end{array}$ & T. ivorensis $\operatorname{Mean}\left(\mathrm{Kg} / \mathrm{m}^{3}\right)$ & D. oliveri Mean $\left(\mathrm{Kg} / \mathrm{m}^{3}\right)$ \\
\hline $20 \% \mathrm{AAE}$ & $130.55 \pm 41.27^{\mathrm{a}}$ & $134.45 \pm 28.46^{\mathrm{ab}}$ & $175.01 \pm 63.39^{\mathrm{a}}$ \\
\hline $30 \% \mathrm{AAE}$ & $105.55 \pm 38.16^{\mathrm{a}}$ & $137.79 \pm 28.75^{\mathrm{a}}$ & $162.50 \pm 90.66^{\mathrm{ab}}$ \\
\hline $50 \% \mathrm{AAE}$ & $124.99 \pm 52.25^{\mathrm{a}}$ & $142.04 \pm 25.72^{\mathrm{a}}$ & $111.39 \pm 68.56^{\mathrm{b}}$ \\
\hline $20 \%$ AME & $111.11 \pm 34.03^{\mathrm{a}}$ & $126.55 \pm 25.28^{\mathrm{ab}}$ & $106.11 \pm 43.01^{\mathrm{b}}$ \\
\hline $30 \%$ AME & $105.55 \pm 70.19^{\mathrm{a}}$ & $122.43 \pm 43.07^{\mathrm{ab}}$ & $124.99 \pm 38.59^{a b}$ \\
\hline $50 \%$ AME & $105.55 \pm 34.77^{\mathrm{a}}$ & $120.68 \pm 32.96^{\mathrm{ab}}$ & $96.94 \pm 59.25^{\mathrm{ab}}$ \\
\hline Solignum & $93.04 \pm 35.98^{\mathrm{a}}$ & $100.54 \pm 29.80^{\mathrm{b}}$ & $108.32 \pm 37.93^{b}$ \\
\hline
\end{tabular}

Key:

Means in the same column (within species) with different superscript are statistically significant $(p<0.05)$. AAE $=A$. afzeliana Aqueous Extract; $A M E=A$. afzeliana Methanol Extract

Retention of treatments in the treat wood samples

Mean retention values in G. arborea, T. ivorensis and D. oliveri wood samples ranged between $9.29-62.51 \mathrm{~kg} / \mathrm{m}^{3}, 11.29-90.78$ $\mathrm{kg} / \mathrm{m}^{3}$ and $10.79-55.69 \mathrm{~kg} / \mathrm{m}^{3}$ with lowest in solignum and highest in $50 \%$ A. afzeliana aqueous extract. There were significant difference $(\mathrm{p}>0.05)$ among treatments in all wood species treated (Table 3$)$.

Table 3: Percentage Retention of Extracts by Three Selected Test Wood Species

\begin{tabular}{|c|c|c|c|}
\hline \multirow[b]{2}{*}{ Treatments } & \multicolumn{3}{|c|}{ Treated wood species } \\
\hline & $\begin{array}{c}\text { Gmelina arborea } \\
\text { Mean }\left(\mathrm{Kg} / \mathrm{m}^{3}\right)\end{array}$ & $\begin{array}{c}\text { Terminelia ivorensis } \\
\text { Mean }\left(\mathrm{Kg} / \mathrm{m}^{3}\right)\end{array}$ & $\begin{array}{c}\text { Daniellia oliveri } \\
\text { Mean }\left(\mathrm{Kg} / \mathbf{m}^{3}\right)\end{array}$ \\
\hline $20 \% \mathrm{AAE}$ & $26.12 \pm 8.25 \mathrm{bc}$ & $34.59 \pm 12.59$ bc & $34.99 \pm 12.67^{\mathrm{ab}}$ \\
\hline $30 \% \mathrm{AAE}$ & $31.67 \pm 11.44^{b}$ & $51.79 \pm 13.74^{b c}$ & $48.73 \pm 27.21^{\mathrm{a}}$ \\
\hline $50 \% \mathrm{AAE}$ & $62.51 \pm 26.10^{\mathrm{a}}$ & $90.78 \pm 26.62^{\mathrm{a}}$ & $55.69 \pm 34.28^{\mathrm{a}}$ \\
\hline $20 \% \mathrm{AME}$ & $22.23 \pm 6.79^{b c}$ & $31.56 \pm 10.43^{\mathrm{c}}$ & $21.22 \pm 8.60^{b c}$ \\
\hline $50 \% \mathrm{AME}$ & $52.79 \pm 17.36^{\mathrm{a}}$ & $75.26 \pm 27.77^{\mathrm{a}}$ & $48.49 \pm 29.63^{\mathrm{a}}$ \\
\hline & $9.29 \pm 3.60^{c}$ & $11.29 \pm 5.02^{\mathrm{d}}$ & $10.79 \pm 3.78^{\mathrm{c}}$ \\
\hline
\end{tabular}

Key:

Means on the same column (within species) with different superscript are statistically significant $(p<0.05)$.

$A A E=A$. afzeliana Aqueous Extract; $A M E=A$. afzeliana Methanol Extract

Incidence of termite attack on $G$. arborea, $T$. ivorensis and D. oliveri test wood samples

Mean weight loss in treated wood samples was $13.81-30.65 \%$ (G. arborea), $13.37-23.31 \%$ (T. ivorensis $36.07-86.11 \%$ (D. oliveri), respectively. The weight loss was in decreasing order of $T$. ivorensis $<G$. arborea $<D$. oliveri. Among all treatments, solignum performed best with record of weight loss of 13.37 in T. ivorensis, $13.81 \%$ in G. arborea and 36.07 in $D$. oliveri test woods. Next to solignum in order of efficacy was $20 \% \mathrm{~A}$. afzeliana methanol extract which recorded weight loss of $17.77 \%$ in G. arborea and 19.72 in T. ivorensis. There were no significant differences $(\mathrm{p}>0.05)$ between $T$. ivorensis and $D$. oliveri weight loss among all treatments. However, there was significant difference $(\mathrm{p}>0.05)$ in weight loss of $G$. arborea treated samples treated with solignum and $A$. afzeliana extracts with the untreated in the (Table 5). 
Table 4: Incidence of termite attack on selected wood species treated with Anadelphia afzeliana extracts

\begin{tabular}{|c|c|c|c|c|c|c|c|c|c|}
\hline \multirow[t]{2}{*}{ Species } & \multirow[b]{2}{*}{ Week } & \multicolumn{8}{|c|}{ Treatments } \\
\hline & & $\begin{array}{l}20 \% \\
\text { AAE }\end{array}$ & $\begin{array}{l}30 \% \\
\text { AAE }\end{array}$ & $\begin{array}{l}50 \% \\
\text { AAE }\end{array}$ & $\begin{array}{r}20 \% \\
\text { AME } \\
\end{array}$ & $\begin{array}{r}30 \% \\
\text { AME } \\
\end{array}$ & $\begin{array}{r}\mathbf{5 0 \%} \\
\text { AME } \\
\end{array}$ & Solignum & $\begin{array}{c}\text { Untreated wood } \\
\text { (Control) }\end{array}$ \\
\hline \multirow[t]{7}{*}{ G. arborea } & $2^{\text {nd }}$ & - & - & - & - & - & - & - & - \\
\hline & $4^{\text {th }}$ & - & + & + & - & - & + & - & + \\
\hline & $6^{\text {th }}$ & + & + & + & + & + & + & - & + \\
\hline & $8^{\text {th }}$ & + & + & + & + & + & + & + & + \\
\hline & $10^{\text {th }}$ & + & + & + & + & + & + & + & + \\
\hline & $12^{\text {th }}$ & + & + & + & + & + & + & + & + \\
\hline & $14^{\text {th }}$ & + & + & + & + & + & + & + & + \\
\hline \multirow[t]{7}{*}{ T. ivorensis } & $2^{\text {nd }}$ & - & - & - & - & - & - & - & - \\
\hline & $4^{\text {th }}$ & + & - & + & - & + & + & - & + \\
\hline & $6^{\text {th }}$ & + & - & + & - & + & + & - & + \\
\hline & $8^{\text {th }}$ & + & + & + & - & + & + & - & + \\
\hline & $10^{\text {th }}$ & + & + & + & + & + & + & + & + \\
\hline & $12^{\text {th }}$ & + & + & + & + & + & + & + & + \\
\hline & $14^{\text {th }}$ & + & + & + & + & + & + & + & + \\
\hline \multirow[t]{7}{*}{ D. oliveri } & $2^{\text {nd }}$ & + & + & + & + & + & + & - & + \\
\hline & $4^{\text {th }}$ & + & + & + & + & + & + & - & + \\
\hline & $6^{\text {th }}$ & + & + & + & + & + & + & - & + \\
\hline & $8^{\text {th }}$ & + & + & + & + & + & + & + & + \\
\hline & $10^{\text {th }}$ & + & + & + & + & + & + & + & + \\
\hline & $12^{\text {th }}$ & + & + & + & + & + & + & + & + \\
\hline & $14^{\text {th }}$ & + & + & + & + & + & + & + & + \\
\hline
\end{tabular}

Key: $A A E=A$. afzeliana Aqueous Extract; $A M E=A$. afzeliana Methanol Extract oliveri test woods. Next to solignum in order of efficacy was

Percentage weight loss of treated wood samples at $14^{\text {th }}$ week of the study

Mean weight loss in treated wood samples was $13.81-30.65 \%$ (G. arborea), $13.37-13.37 \%$ (D. oliveri) $36.07-86.11 \%$ (T. ivorensis), respectively. The weight loss was in decreasing order of $T$. ivorensis $<G$. arborea $<D$. oliveri. Among all treatments, solignum performed best with record of weight loss $20 \% \mathrm{~A}$. afzeliana methanol extract which recorded weight loss of $17.77 \%$ in G. arborea and 19.72 in T. ivorensis. There were no significant differences $(\mathrm{p}>0.05)$ between T. ivorensis and $D$. oliveri weight loss among all treatments. However, there was significant difference $(\mathrm{p}>0.5)$ between solignum and $A$. afzeliana extracts in the weight loss of G. arborea treated samples (Table 5).

of 13.37 in T. ivorensis, $13.81 \%$ in G. arborea and 36.07 in D.

Table 5: Percentage weight loss of treated wood samples at $14^{\text {th }}$ week of the study

\begin{tabular}{lccc}
\hline Treatments & $\begin{array}{c}\text { Gmelina arborea } \\
\text { Mean } \pm \text { SD (\%) }\end{array}$ & $\begin{array}{c}\text { Terminelia ivorensis } \\
\text { Mean } \pm \text { SD (\%) }\end{array}$ & $\begin{array}{c}\text { Daniellia oliveri } \\
\text { Mean } \pm \text { SD (\%) }\end{array}$ \\
\hline $20 \%$ AAE & $19.63 \pm 2.33^{\mathrm{a}}$ & $21.57 \pm 3.99^{\mathrm{a}}$ & $39.51 \pm 5.95^{\mathrm{b}}$ \\
$30 \%$ AAE & $23.79 \pm 2.01^{\mathrm{a}}$ & $22.37 \pm 3.12^{\mathrm{a}}$ & $67.14 \pm 8.87^{\mathrm{ab}}$ \\
$50 \%$ AAE & $26.43 \pm 5.71^{\mathrm{a}}$ & $20.47 \pm 2.41^{\mathrm{a}}$ & $36.26 \pm 3.72^{\mathrm{b}}$ \\
$20 \%$ AME & $17.77 \pm 1.71^{\mathrm{a}}$ & $19.72 \pm 2.61^{\mathrm{a}}$ & $58.90 \pm 10.07^{\mathrm{ab}}$ \\
$30 \%$ AME & $28.77 \pm 2.25^{\mathrm{a}}$ & $20.79 \pm 3.19^{\mathrm{a}}$ & $36.26 \pm 6.73^{\mathrm{b}}$ \\
$50 \%$ AME & $26.96 \pm 5.58^{\mathrm{a}}$ & $21.24 \pm 2.65^{\mathrm{a}}$ & $84.26 \pm 6.19^{\mathrm{a}}$ \\
Solignum (+ Control) & $13.81 \pm 2.28^{\mathrm{b}}$ & $13.37 \pm 2.53^{\mathrm{a}}$ & $36.07 \pm 3.72^{\mathrm{a}}$ \\
Untreated wood (- Control) & $30.65 \pm 2.25^{\mathrm{a}}$ & $23.31 \pm 2.90^{\mathrm{a}}$ & $86.11 \pm 7.58^{\mathrm{a}}$ \\
\hline
\end{tabular}

Key:

Means on the same column (within species) with different superscript are statistically significant $(p<0.05)$.

$A A E=$ A. afzeliana Aqueous Extract; $A M E=A$. afzeliana Methanol Extract

Visual rating of treated wood samples after preservative treatments

Gmelina arborea wood treated with $20 \%$ A. afzeliana aqueous extract, $20 \%$ A. afzeliana methanol extract and solignum were slightly attacked by termites. Also, T. ivorensis wood treated with $20 \%$ A. afzeliana aqueous extract and solignum were also 
slightly attacked. The visual rating revealed that $D$. oliveri wood was the most attached wood samples by termites (Table 6). Table 6: Visual Rating of Treated Wood Samples at Expiration of Experiment

\begin{tabular}{lccc}
\hline \multirow{2}{*}{ Treatments } & \multicolumn{3}{c}{ Visual rating of treated wood samples } \\
\cline { 2 - 4 } & Gmelina arborea & Terminalia ivorensis & Daniellia oliveri \\
\hline $20 \%$ AAE & 1 & 2 & 2 \\
$30 \%$ AAE & 2 & 2 & 4 \\
$50 \%$ AAE & 2 & 2 & 2 \\
$20 \%$ AME & 1 & 1 & 3 \\
$30 \%$ AME & 2 & 2 & 2 \\
$50 \%$ AME & 2 & 2 & 5 \\
Solignum & 1 & 1 & 2 \\
Control & 2 & 2 & 5 \\
\hline
\end{tabular}

Key:

$0=$ No attack; 1 = Slight attack $(1-20 \%$ damage $) ; 2=$ Moderate attack $(21-40 \%$ damage $) ; 3=$ Moderate/severe attack $(41-$ $60 \%$ damage $) ; 4=$ severely attack $(61-80 \%$ damage $) ; 5=$ Very severely attack $(81-99 \%$ damage $) ;$

$6=100 \%$ failure

\section{DISCUSSION}

Anthraquinones, balsams, flavonoids, phlobatannins, tannins, terpens, resins, phenols and saponins phytochemicals were screened from $A$. afzeliana from methanol and aqueous extracts. High contents of tannins and alkaloid in Capsicum frutescens, Croton tiglium, Peganum harmala and Ricinus communis was reported to have antitermitic activity. Saponins are produced by plants as a protective instrument to inhibit the attacks by foreign pathogens (Abbas et al., 2013; Okwu et al., 2006; Nwinuka et al., 2005). For the protection of emergent seedlings and maturing as well as pre-harvest agricultural crops, anthraquinone-based repellents have been tested to be effective foliar applications (DeLiberto and Werner, 2016). Gebashe et al. (2020) reported soluble flavonoids, proanthocyanidins, iridoids, phenolic content, and phenolic acids phytochemicals from the profiles of thirteen medicinal grasses used for traditional medicine in South African. Ekhuemelo et al., (2018b) characterized stigmasterol from $A$. afzeliana. The potential effect of $A$. afzeliana to prevent or control the rate of termite activity could be the presence of resins in both methanol and aqueous extracts. Aqueous extracts had high presence of resins and saponins than in methanol extract which was fairly present. This result is in accordance with the report of Verma and Verma (2006) which reported that resins inhibit termite growth rate, reduce the frequency of termite feeding and have high toxicity level.

The absorption of extracts treated wood was highest with aqueous extracts compared to methanol extracts. This is in line with ASTM (2007) report that absorption of water soluble preservatives is higher than that of oil base. This may be because water fills the air space in the wood. Likewise differences in the level of absorption among the preservatives could be due to the cell structure of the wood species, as reported by Dinwodie (1981). Viscosity is a function of absorption by the wood. The more viscous a preservative is, the lower the flow per unit time and the less the absorption especially for non-pressure treatment method (Adeduntan, 2015). Absorption could be enhanced by heating the preservative chemicals or further dilution with solvent as in case of oil borne preservatives (Owoyemi, 2000). The quantity of extracts absorbed by wood samples did not determine the level of effectiveness of the extracts on the activities of termites in the study. Solignum treatment was the least absorbed treatment, yet it was the most effective treatment.
Mean retention of treatments in test wood was maximum in $T$. ivorensis followed by and $D$. oliveri $G$. arborea. It was also highest with $50 \% \mathrm{~A}$. afzeliana aqueous extract and lowest in solignum treatment. Retention of treatments in treated wood, increased with increase percentage of extracts as $50 \%>$ $30 \%>20 \%$. This trend had inverse impact on the weight loss of treated wood as there was decrease in weight loss of treated woods with increase in percentage of extracts. It therefore implied that, the lower the concentration of the extract, the more effective the extracts. The resistance of test woods to termite attack was more on the natural durability of the wood species. The resistance of attack by treated wood could also be due to the active ingredient of the preservative chemical as observed by Adeduntan (2015). This result is similar to the observation of Schultz et al. (2005), who reported that wood exhibits variation in absorption and retention of chemical preservatives when treated. The variation in the preservative retention, according to them could affect the life span of individual wood products. This implies that the amount of preservative retained in the cellulose materials varied according to anatomical structures of the various wood species.

D. oliveri test wood samples had the highest percentage weight loss and the most susceptible to termite attack followed by G. arborea and T. ivorensis wood samples. This implies that $D$. oliveri wood was more vulnerable to termites and should be well treated before service. This result is in line with the work of Ekhuemelo and Musa (2015) who reported that D. oliveri susceptible to termites attack as such needs protection before employed in service. In this study, solignum proved to be the most active treatment followed by $20 \%$ A. afzeliana methanol extract.

\section{CONCLUSION}

Phytochemical screening of A. afzelia revealed moderate presence of anthraquinones, balsams, flavonoids, phlobatannins, tannins and terpens in methanol extract, while, phlobatannins, resins and saponins were slightly present in the aqueous extract. The higher the concentration of $A$. afzelia extract, the higher the mean percentage absorption and retention in wood samples. Absorption of treatments was highest in D. oliveri, while retention was maxumum in $T$. ivorensis. Percentage weight loss was least in solignum treated woods followed by $20 \%$ A. afzelia methanol extract. D. oliveri test wood samples had the highest percentage weight loss. 
Among $A$. afzelia extracts, $20 \% \mathrm{~A}$. afzelia methanol extract was the most efficient while $T$. ivorensis was most resistant to termite attack.

\section{REFERENCES}

Abbas, M., Shahid, M., Iqbal, M., Anjum, F., Sharif, S., Ahmed, S. and Pirzada, T., 2013. Antitermitic activity and phytochemical analysis of fifteen medicinal plant seeds Journal of Medicinal Plants Research, 7(22): 1608-1617.

Adedeji, G.A, Ogunsanwo O.Y and Aiyeloja, A. A. (2013). Characterisation of Solvent Components in Erythrophleum suaveolens (Guill. \& Perr.) Brenan Stem Bark Extracts Treated Triplochiton scleroxylon K. Schum Wood. International Journal of Scientific \& Engineering Research, 4(10): 926

Adedutan, S.A., (2015). The Termicidal Effect of Some Plant Materials on Some Selected Wood Species. International Journal of Biological and Chemical Sciences, 9(2): 986-995.

American Society for Testing and Materials (2007). Preparation of decayed wood for microscopical examination. ASTM D1413-61.

AOAC, (2010). Official Methods of Analysis of Association of Official Analytical Chemists. 18th Edition, Washington, DC.

Bagué, S. A. J., (2011). Anadelphia afzeliana (Rendle) Stapf. Record from PROTA4U. Brink, M. and Achigan-Dako, E.G (Editors). PROTA (Plant Resources of Tropical Africa / Ressources végétales de l'Afrique tropicale), Wageningen, Netherlands. $\quad$ https://uses.plantnet project.org/en/Anadelphia afzeliana (PROTA)

Barnes, H.M. (1992). Wood Protecting Chemicals from the $21^{\text {st }}$ century. International Research Group on wood preservation, 24th Annual Conference Meeting at Orlando, Florida, USA, 16-20 May 1992, IRG/WP 93-30018. 29p

Brink, M. and Achigan-Dako, E.G. (2012). Plant Resources of Tropical Africa 16. Fibres. Prota Fundation, Wegeningen, Netherlands/CTA. Pp 602.

Connel, M. (1991). Industrial Wood Preservatives the History Development, Use, Advantages and Future Trends. The Chemistry of Wood Preservation. Woodhead Publishing. Pp316DeLiberto, S. T., and Werner, S. J. (2016). Review of anthraquinone applications for pest management and agricultural crop protection. Pest Management Science, 72(10), 1813-1825. doi: $10.1002 /$ ps. 4330

Dinwodie, J.M. (1981). Timber: Its Nature and Behaviour. Van Nostrand Reinhold Co. Ltd. Berkshire, England. Pp 170.

Ekhuemelo D. O., Abu, V. E. and Anyam, J. V. (2017). Termiticidal Evaluation of Jatropha curcas (Linn), Thevetia peruviana (Pers) and Moringa oleifera (Lam) Seed Extracts on Gmelina arborea (Roxb) and Daniellia oliveri (Rolfe) Wood. World Journal of Applied Chemistry, 2(3): 101-108.

Ekhuemelo, D. O. and Musa, M. (2015). Antitermitic effect of Moringa oleifera Extracts on Gmelina arborea and Ceiba pentandra wood. Nigerian Journal of Agriculture, Food and Environment. 11(3):55-60.

Ekhuemelo, D. O. Tembe, E. T., and Zinga, Z. Y. (2018a). Termiticidal effect of cold-water extracts of Erythrophleum suaveolens (Guill. \& Perr.) Brenan stem bark and sawdust on Daniella oliveri (Rolfe) and Gmelina arborea (Roxb) wood samples. African Journal of Agriculture Technology and Environment, 7(2): 138-152.

Ekhuemelo, D. O., Agbidye, F. S., Anyam, J. V. and Ugba, R. B. (2018b). Antimicrobial effect of isolated compound of Anadelphia afzeliana (Rendle) Stapf on selected wood fungi and bacteria in Makurdi, Nigeria. Nigerian Journal of Biotechnology, 35(2): 108-120.

Emerhi, E. A., Adedeji, G. A. and Ogunsanwo, O. Y. (2015). Termites' resistance of wood treated with Lagenaria breviflora B. Robert fruit pulp extract. Nature and Science, 13(5): $105-$ 109.

Ezeji, S.C.O.A. (1984). Building construction. Harlow, England: Longman Group Limited. Pp 135.

Falemara, B.C., Olufemi, B. and Owoyemi, J. M. (2012). Physical properties of ten Selected indigenous wood species in Nigeria. In: Adebayo, I.A; Adekunle,V.A.J; Oseni, J.O; Awodun,M.A.(2012) (eds): Proceedings of the 6th Annual Agriculture Conference :Research and Capacity Building for Agricultural Transformation in Nigeria, 7-9, Nov 2012, held at Federal University of Technology, Akure, Ondo State, Nigeria. Pp. 168- 178.

Gebashe, F., Aremu, A. O., Gruz, J., Finnie, J. F., and Van Staden, J. (2020). Phytochemical Profiles and Antioxidant Activity of Grasses Used in South African Traditional Medicine. Plants, 9(3), 371. doi:10.3390/plants9030371

Goktas, O. Mamodoo, R. Emin, M. D., Ertan, O. Imelda, A.C. and Ferah Y. (2007). Introduction and Evaluation of Wood Preservative Potentials of Poisonous Sternbergia candidum extracts. African Journal of biotechnology, 6(8): 982-986.

Jerrold, E.W. (2005). Wood Properties In: Arntzen, Charles J., ed. Encyclopaedia of Agricultural Science. Orlando, FL: Academic Press: 549-561.

Kartal, S. N., Yoshimura, T., and Imamura Y. (2004). Decay and Termite Resistance of Boron-Treated and Chemically Modified Wood by In Situ Co-Polymerization of Allyl Glycidyl Ether (Age) With Methyl Methacrylate(MMA). International Biodeterioration and Biodegradation, 53:111-117.

Mbahi, M. A., Mbahi, A. M., Umar, I. A., Ameh, D. A., Joseph, I. and Amos, P. I. (2018) Phytochemical Screening and Antimicrobial Activity of the Pulp Extract and Fractions of Ziziphus mauritiana. Biochemistry and Analytical Biochemistry, 7: 352 .

Obi, J. C., Ogunkunle A. O. and N.T. Meludu, (2008). Effect of Termite Infestation on the Farming System Characteristics of 
an Endemic Area In The Guinea Savanna Region of Nigeria. American-Eurasian Journal of Scientific Research, 3(1): 1-6.

Okwu, D. E., and Emenike I. N. (2006). Evaluation of the phytonutrients and vitamin contents of citrus fruits International Journal of Molecular Medicine and Advance Sciences, 2(1):1-6.

Owoyemi, J. M. (2000). Resistance of Gmelina arborea (Roxb) treated with some wood Preservatives to subterranean termites, $35-45$.

Owoyemi J. M. and Olaniran O. S. (2014). Natural Resistance of Ten Selected Nigerian Wood Species to Subterranean Termites' Attack. International Journal of Biological Sciences and Applications, 1(2): 35-39.

Owusu, E. O., (2000). Effect of some Ghanaian Plant Components on Control of Two Stored-Product insect pests of Cereals, Journal of Stored Products Research, 37: 85-91.

Nwinuka, N. M., Ibeh G. O., and Ekeke, G. I. (2005). Proximate composition and levels of some toxicants in four commonly consumed spices. Journal of Applied Sciences and Environmental Management, 9(1):150-155.

Peralta, E. B., Acacia G. C. and Elendilima, A. M. (2004). Wood Consumption Rates of Forest Species By Subterranean Termites (Isoptera) Under Field Condition. Revista Árvore, 28(2): $284-289$.
Schultz, T.P., Nicholas, D. D., Henry, W.P. Pitman, C.U., Wipf O., and Goodell, B. (2005). Review of Labouratory and Outdoor Exposure Efficacy Results of Organc Biocide Antioxidant Combination and Initial Economic Analysis and Discussion of Proposed Mechanism. Wood and Fiber Science, 37(1): 175-184.

Sonowal, J. and Gogoi, P.K. (2010). Dimensional Stability, Thermal Degradation and Termite Resistant Studies of Chemically Treated Wood. International Journal of Chemistry Archives, 2(2): 218 - 225.

Sotannde O. A., Gabriel O. Yager, Bamidele D. Zira and Abubakar Usman (2011). Termiticidal effect of Neem Extracts on the wood of Khaya senegalensis Research Journal of Forestry, 5: 128-138.

Tascioglu, C., Yalcin, M., Sen, S., and Akcay, C. (2013). Antifungal properties of some plant extracts used as wood preservatives. International Biodeterioration and Biodegradation, 85, 23-28.

Unger A., Schniewind A.P. and Unger W. (2001). Consolidants. In: Conservation of Wood Artifacts. Natural Science in Archaeology. Springer, Berlin, Heidelberg. https://doi.org/10.1007/978-3-662-06398-9 12

Verma, R.K. and Verma S. K. (2006). Phytochemical and Termiticidal Study of Lantana camara Var. aculeata Leaves, Fitoterapia, 77: 466-468. 